\title{
Neuroprotection signaling pathway of nerve growth factor and brain-derived neurotrophic factor against staurosporine induced apoptosis in hippocampal H19-7 cells
}

\author{
Truong LX Nguyen ${ }^{1}$, Chung Kwon Kim ${ }^{1}$, \\ Jun-Hee $\mathrm{Cho}^{4}$, Kyung-Hoon Lee ${ }^{2,3}$ and \\ Jee-Yin Ahn ${ }^{1,3,5}$ \\ ${ }^{1}$ Department of Molecular Cell Biology \\ ${ }^{2}$ Department of Anatomy \\ ${ }^{3}$ Center for Molecular Medicine \\ Samsung Biomedical Research Institute \\ Sungkyunkwan University School of Medicine \\ Suwon 440-746, Korea \\ ${ }^{4}$ Posung High School \\ Seoul 138-050, Korea \\ ${ }^{5}$ Corresponding author: Tel, 82-31-299-6134; \\ Fax, 82-31-299-6139; E-mail, jyahn@med.skku.ac.kr \\ DOI 10.3858/emm.2010.42.8.060
}

Accepted 15 July 2010

Available Online 19 July 2010

Abbreviations: p75NTR, p75 neurotrophin receptor; PI3K, phosphatidyl inositol 3 kinase; Trk, tropomyosin receptor kinase

\begin{abstract}
Neurotrophins protect neurons against excitotoxicity; however the signaling mechanisms for this protection remain to be fully elucidated. Here we report that activation of the phosphatidyl inositol 3 kinase (PI3K)/Akt pathway is critical for protection of hippocampal cells from staurosporine (STS) induced apoptosis, characterized by nuclear condensation and activation of the caspase cascade. Both nerve growth factor (NGF) and brain-derived growth factor (BDNF) prevent STS-induced apoptotic morphology and caspase-3 activity by upregulating phosphorylation of the tropomyosin receptor kinase (Trk) receptor. Inhibition of Trk receptor by K252a altered the neuroprotective effect of both NGF and BDNF whereas inhibition of the p75 neurotrophin receptor (p75NTR) had no effect. Impairment of the PI3K/Akt pathway or overexpression of dominant negative (DN)-Akt abolished the protective effect of both neurotrophins, while active Akt prevented cell death. Moreover, knockdown of Akt by si-RNA was able to block the survival effect of both NGF and BDNF. Thus, the survival action of NGF and BDNF against
\end{abstract}

STS-induced neurotoxicity was mediated by the activation of PI3K/Akt signaling through the Trk receptor.

Keywords: brain-derived neurotrophic factor; cell survival; nerve growth factors; phosphatidylinositol 3 kinase; protein kinase B; receptor, trkA

\section{Introduction}

The survival function of neurotrophins is mediated through the activation of two cell surface receptors, the Trk family and the p75 neurotrophin (p75NTR) receptor (Levi-Montalcini, 1987; Huang and Reichardt, 2003). The latter binds to all neurotrophins with low affinity, whereas the TrkA, TrkB, and TrkC receptors bind to NGF, BDNF and NT-3 respectively (Chao, 2003). TrkA activation is important for the survival and differentiation of neurons. When p75NTR is activated in the absence of a strong Trk signal, it induces apoptosis of neurons. However, in the presence of Trk, p75NTR enhances the response to neurotrophins. These varying responses point to a complex interplay between neurotrophin-stimulated survival, differentiation, and apoptosis pathways (Kaplan and Miller, 1997). Through Trk receptors, neurotrophins activate many intracellular signaling pathways including those controlled by Ras, leading to the activation of the mitogen activated protein kinase (MAPK), phospholipase C (PLC)- $\gamma 1$, and phosphatidyl inositol 3-kinase (PI3K)/Akt, thereby affecting both development and function of the nervous system (Patapoutian and Reichardt, 2001). However, PI3K/Akt pathway is particularly important for mediating neuronal survival under a wide variety of circumstances (Brunet et al., 2001) and has been found to be sufficient and, in some cases, necessary for the trophic-factor-induced cell survival of several neuronal cell types (Yao and Cooper, 1995; Dudek et al., 1997; Miller et al., 1997; Philpott et al., 1997). Akt acts both prior to the release of cytochrome $c$, by regulating $\mathrm{Bcl}-2$ family member activity and mitochondrial function, and subsequent to the release of cytochrome $c$, by regulating components of the apoptosome. For instance, Akt phosphorylates the pro-apoptotic Bcl-2 family member BAD, thereby inhibiting BAD pro-apoptotic 
functions (Datta et al., 1997; del Peso et al., 1997). Akt also directly phosphorylates and inhibits the caspase proteases including caspase 9 (Cardone et al., 1998). In addition to its effects on the cytoplasmic apoptotic machinery, the PI3K-Akt pathway also regulates apoptosis by suppressing the expression of death genes. For example, Akt controls a major class of transcription factors-the Forkhead box transcription factor by phosphorylating FOXOs (Forkhead box, group $\mathrm{O}$ ) and inhibiting their ability to induce the expression of death genes (Biggs et al., 1999; Brunet et al., 1999; Kops et al., 1999).

It has been shown that there is a basic difference in the response of neurons in the peripheral nervous system (PNS) and central nervous system (CNS) to neurotrophins (Meyer-Franke et al., 1998; Goldberg and Barres, 2000). In the PNS, neuronal survival is dependent on the action of distinct neurotrophins upon different cell types. For example, nerve growth factor (NGF) promotes cell survival in sympathetic and dorsal root ganglia neurons (Crowley et al., 1994; Smeyne et al., 1994). Accumulating evidence suggests that in the CNS, neurons are dependent on a combination of multiple factors, including neurotrophins, for their survival by controlling apoptosis. For instance, brain derived neurotrophic factor (BDNF) and neurotrophin-3 (NT-3) are critical for the survival of newly generated granule neurons in the mouse cerebellum (Bates et al., 1999). Multiple studies have shown that the functions of PI3K in mediating the antiapoptotic effect of NGF in trophic deprived PNS neurons (Yao and Cooper 1995; Klesse et al., 1999; Crowder and Freeman 1998; Klesse and Parada 1998; Meyer-Franke et al., 1998; Vaillant et al., 1999). However, in the CNS, it has been reported that PI3K only partially mediates BDNF mediated survival, revealing neuroprotection by BDNF is also partially dependent on Erk1/2 signaling (Meyer-Franke et al., 1998; Skaper et al., 1998; Takei et al., 1999).

Neuronal apoptosis is not restricted to the developmental stage but also occurs in acute and chronic neurologic disease conditions eliciting the loss of neurons. In the adult CNS, neurons undergo excitotoxic cell death following excessive release of glutamate from presynaptic nerve termini and astrocytes (Olney and Sharpe, 1969; Choi, 1994). Excitotoxicity is considered a major inducer of cell death in acute neurodegenerative conditions. Recent advances indicate that apoptosis is a prominent contributor to excitotoxicity-induced neuronal loss (Martin et al., 1998; Zipfel et al., 2000), which is characterized by the release of cytochrome $\mathrm{C}$, allowing the activation of caspase cascades including the activation of caspase- 9 and 3. Although TrkA mRNA expression is restricted to sensory and sympathetic neurons in the peripheral nervous system, and cholinergic neurons in the basal forebrain (Koh et al., 1989; Ip et al., 1993; Muragaki et al., 1995), TrkB is broadly expressed in various brain regions, with a particular enrichment in hippocampal neurons (Barbacid, 1995). By contrast, TrkA expression was reported to be sparse or absent in hippocampal and cortical neurons under physiological conditions (Ip et al., 1993; Cellerino, 1996; Lee et al., 1998; Friedman, 2000). However, neuroprotection by NGF in hippocampal and cortical neurons has been demonstrated in vitro and in vivo (Zhang et al., 1993; Culmsee et al., 1999, 2002; Kume et al., 2000). In spite of the prominent effect of NGF and BDNF protecting neuronal death in many cell types, the possible comparative effects of these two neurotrophins on survival of hippocampal neurons, and underlying signaling mechanism have not yet been elucidated. In this study, we determined the role of NGF and BDNF in inhibiting apoptotic cell death and the intracellular signaling pathway responsible for this protection under staurosporine (STS) toxicity in H19-7 hippocampal progenitor cells. The H19-7 cells were generated by infecting rat E17 hippocampal cells with a retroviral vector expressing a temperature sensitive SV40 large T antigen; therefore this cell line has a number of features to measure in vivo differentiation and apoptosis during development (Eves et al., 1992, 1994). Our results showed that both NGF and BDNF protect hippocampal progenitor cells and primary hippocampal neurons from STS-induced apoptosis at the level of, or upstream of, caspase-3. Moreover, our data suggest that the PI3K/Akt is both necessary and sufficient for these neurotrophins mediated protection through Trk receptor activation.

\section{Results}

\section{Staurosporine (STS) induces neuronal apoptosis in H19-7 cells and primary hippocampal neurons}

Many important mechanisms involved in apoptosis have been determined using STS or mycotoxin, a general protein kinase inhibitor that triggers apoptosis in model cell lines (Xia et al., 1995; Jacobsen et al., 1996; Seo and Seo, 2009). The intracellular signaling of STS induced apoptosis is dependent on cell type. To determine the effect of STS induced apoptosis in hippocampal neurons, we exposed cultured hippocampal cells to $100 \mathrm{nM}$ 
A
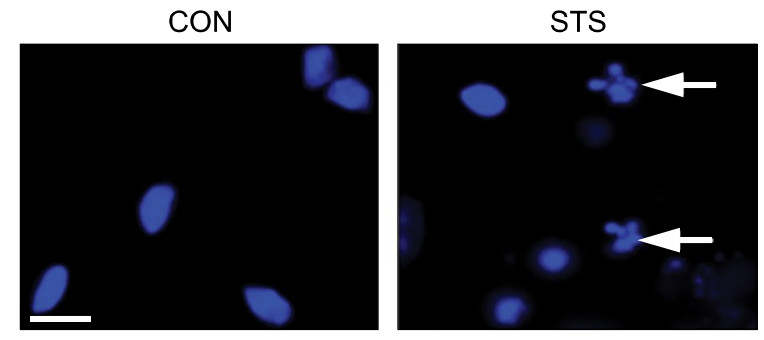

$c$

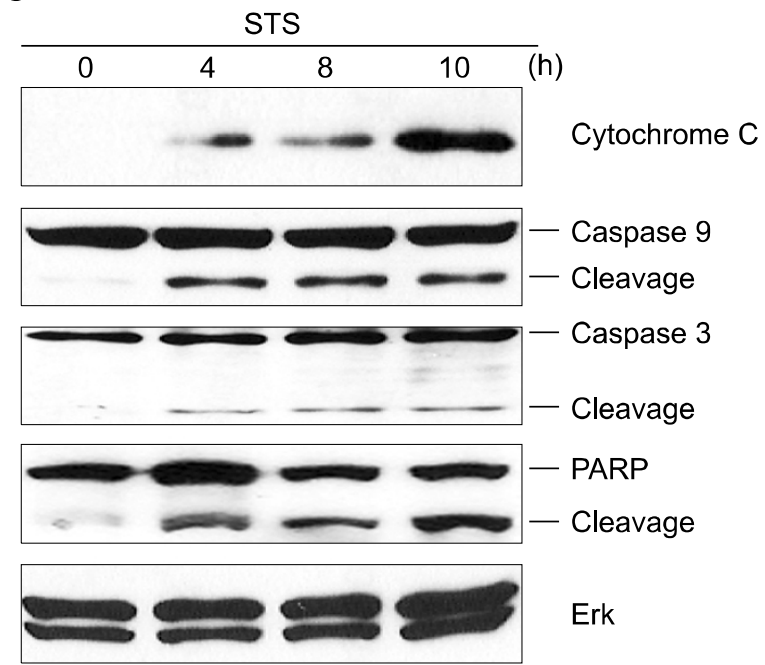

D

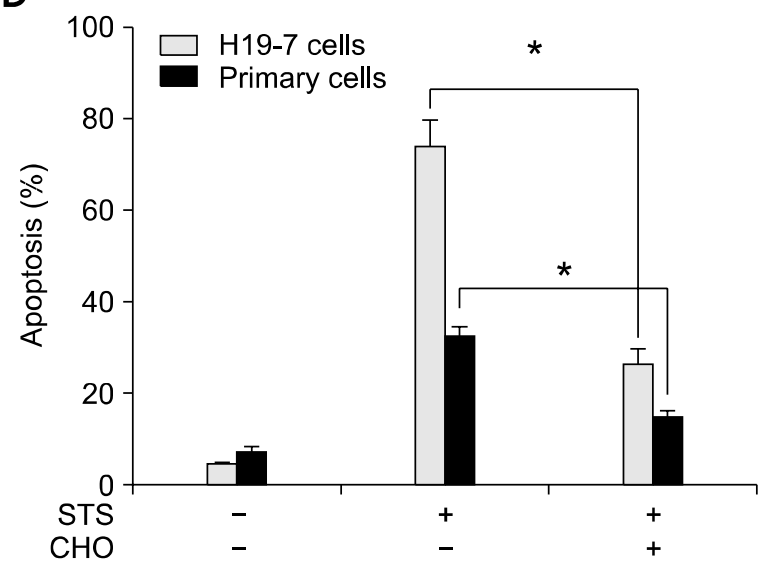

B
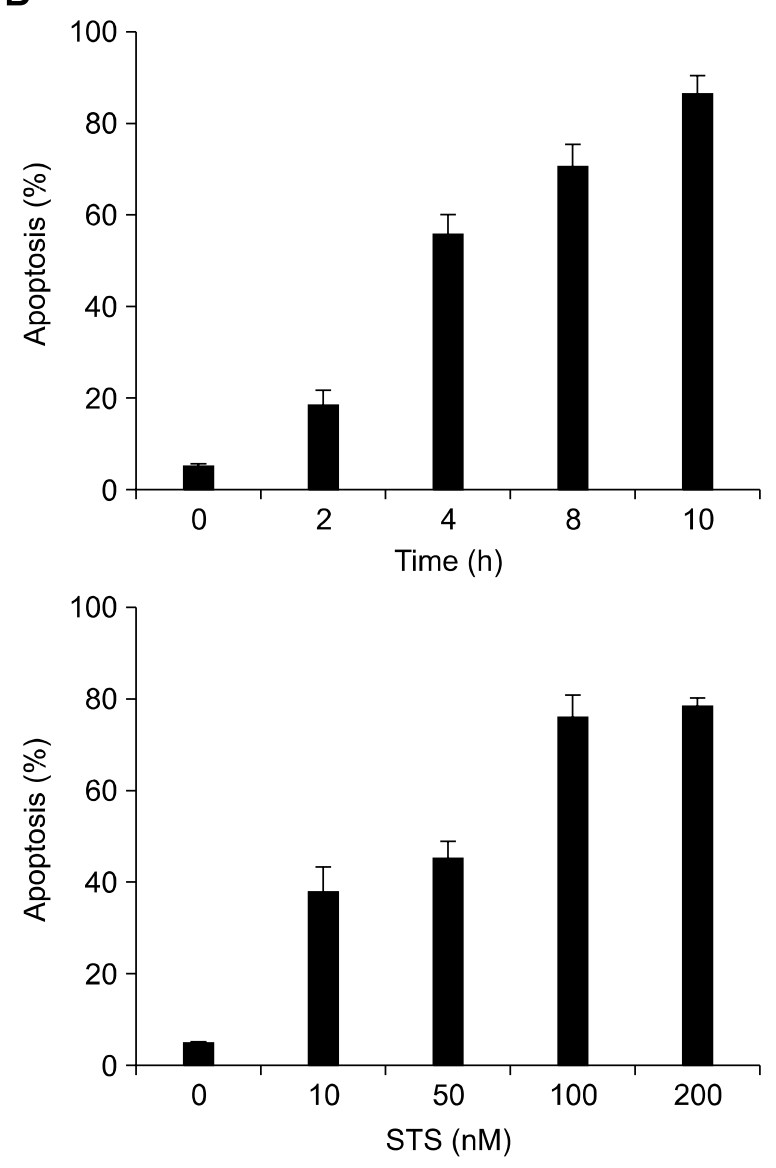

E

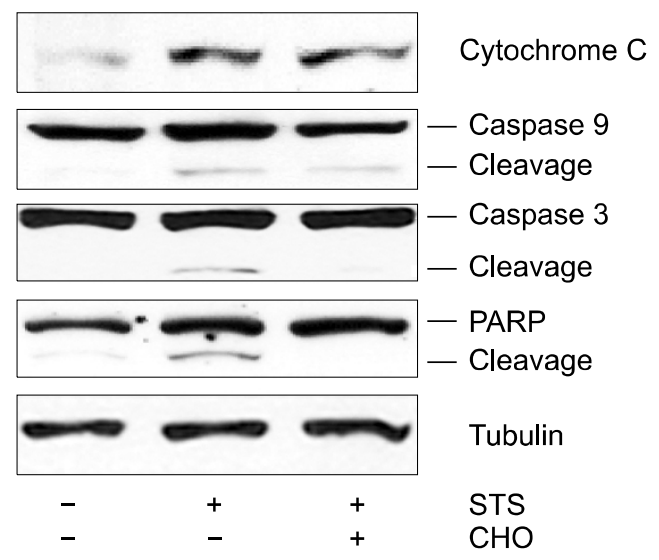

Figure 1. Staurosporine induces neuronal apoptosis. (A) Cultured hippocampal neurons were exposed to $100 \mathrm{nM}$ of STS. After $8 \mathrm{~h}$, apoptotic cell death was determined after nuclei staining with DAPI. All the quantitative analysis of apoptotic nuclei in this report are given as the mean \pm standard error (s.e.) from three separate experiments, ${ }^{*} P<0.05$ (Student's t-test), and all the pictures in this report were taken using a fluorescent microscope $(\times 100)$. White arrows indicate apoptotic and fragmented nuclei. Scale bar $=5 \mu \mathrm{m}$. (B) H19-7 cells were treated with $100 \mathrm{nM}$ STS from 2 to $10 \mathrm{~h}$ (upper) or with STS from $10 \mathrm{nM}$ to $200 \mathrm{nM}$ for 8 hours (lower). Cells were collected at the indicated times and stained with DAPI. (C) H19-7 cells were exposed to $100 \mathrm{nM}$ STS and collected at the indicated times. $30 \mu \mathrm{g}$ of cell lysate was immunoprobed with indicated antibodies. (D) H19-7 cells and cultured hippocampal cells were untreated or treated with caspase 3 inhibitor CHO for 30 min before exposure to $100 \mathrm{nM}$ STS for 8 hours. (E) H19-7 cells were treated as described in (D) and Tubulin was shown as a loading control. 
A

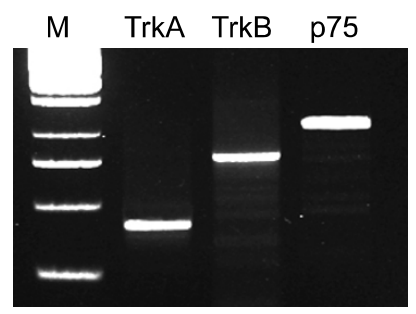

B

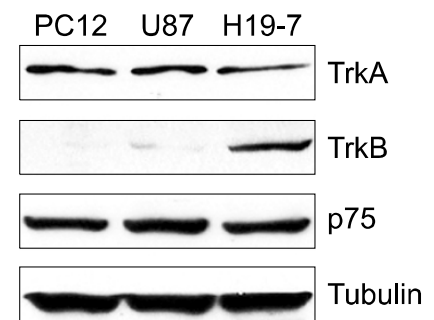

C
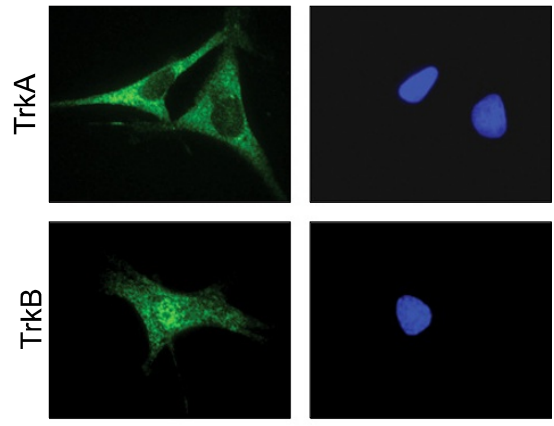

$\stackrel{\text { n }}{\stackrel{2}{2}}$
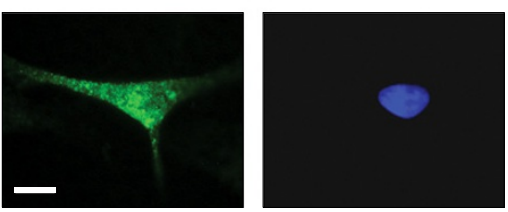

D

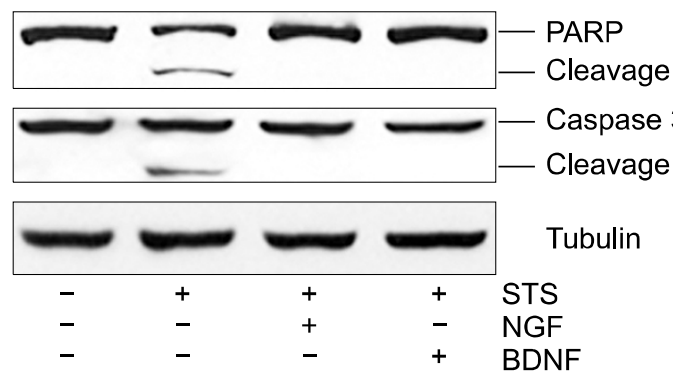

E

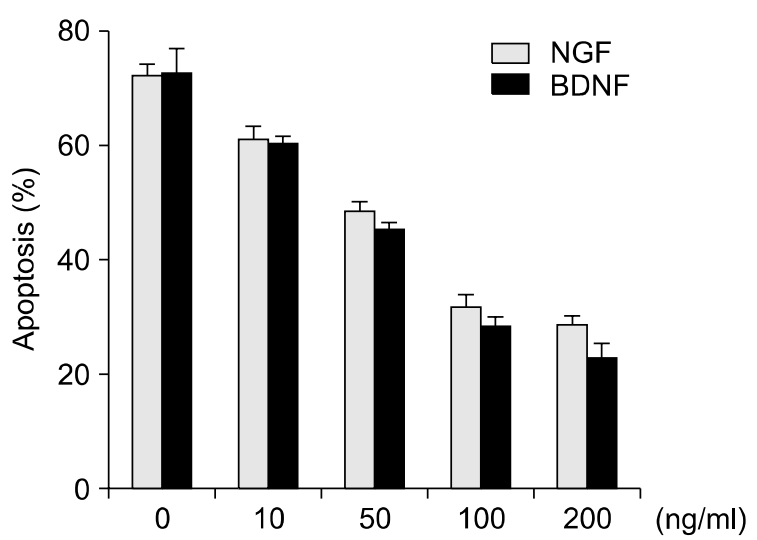

$\mathbf{F}$

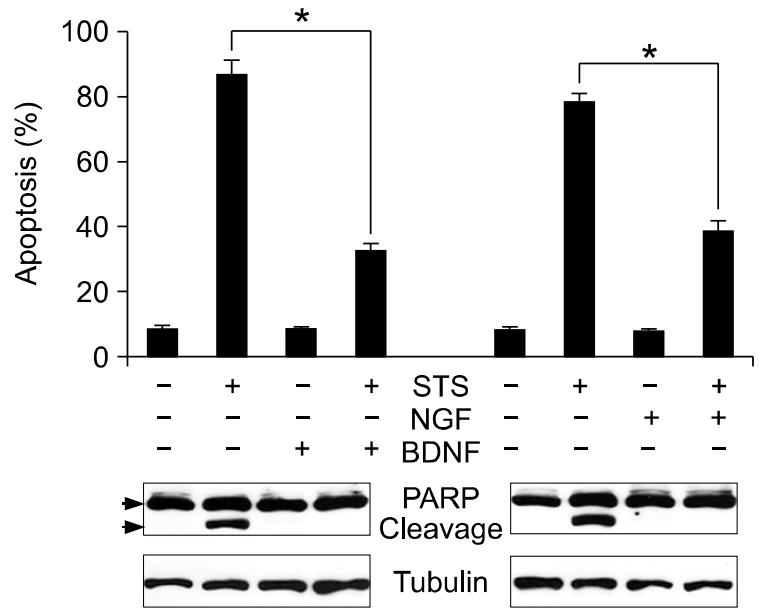

Figure 2. NGF and BDNF protect neuronal cell death from STS. (A) Total RNA was extracted from H19-7 cells and reverse transcription was performed using $1 \mu \mathrm{g}$ of RNA. (B) $30 \mu \mathrm{g}$ of PC12, U87 and H19-7 cell lysates were used for immunoblots with anti-TrkA, anti-TrkB and anti-p75NTR antibodies. (C) H19-7 cells were stained with anti-TrkA, anti-TrkB and anti-p75NTR antibodies. (D) H19-7 cells were untreated or treated with STS in the presence or absence of NGF and BDNF and immunoprobed with indicated antibodies. (E) H19-7 cells were incubated with the indicated concentration of NGF or BDNF for $24 \mathrm{~h}$, followed by exposure to $100 \mathrm{nM}$ STS for $8 \mathrm{~h}$. The cells were then fixed and DAPI stained. Condensed nuclei were counted under the fluorescent microscope. (F) H19-7 cells were untreated or treated with $100 \mathrm{nM}$ STS in the presence or absence of $100 \mathrm{ng} / \mathrm{ml} \mathrm{NGF}$ or BDNF. For counting of nuclear condensation, the cells were fixed and stained with DAPI. ${ }^{*} P<0.05$. For immunoblots, the cells were lysed and immunoprobed with anti-PARP and anti-tubulin antibodies.

STS and cell death was accessed by analyzing nuclear morphology after $8 \mathrm{hrs}$ of apoptotic insult using DAPI staining. Apoptotic insult with STS elicited around $50 \%$ of apoptotic cell morphology with chromatin condensation (Figure 1A). Exposing H19-7 cells to increasing concentrations of STS over varying points periods reveals that cell death is both dose and time dependent (Figure 1B).

Activation of caspase-3 is a hallmark of apoptotic cell death that precedes change in nuclear morphology. Immunoblot analysis shows that a release of cytochrome $\mathrm{C}$, mainly at hour 4 (Figure $1 \mathrm{C} 1^{\text {st }}$ panel), and activation of caspase- 9 with the cleaved, inactive $(19 \mathrm{kDa})$ and active form $(17 \mathrm{kDa})$ (Figure $1 \mathrm{C} 2^{\text {nd }}$ panel), engaged the apoptosome pathway. Caspase-3 activation was observed both directly and indirectly with the appearance of the caspase-3 cleavage form and poly (ADP-ribose) 
A

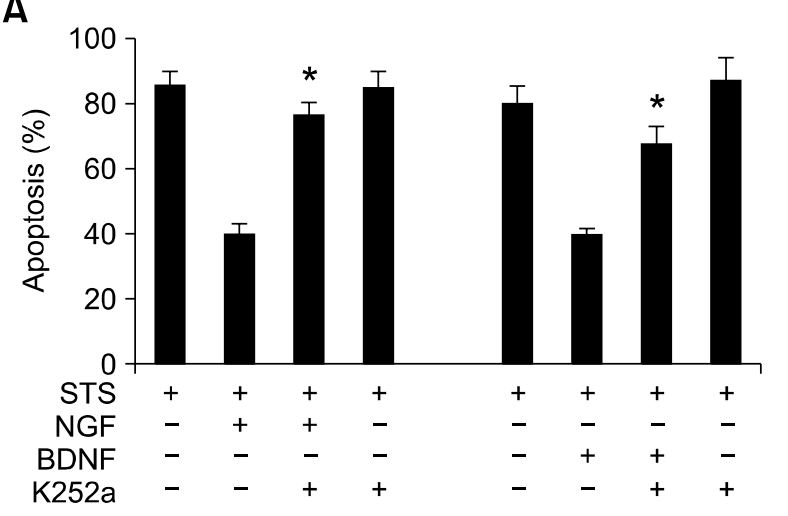

B

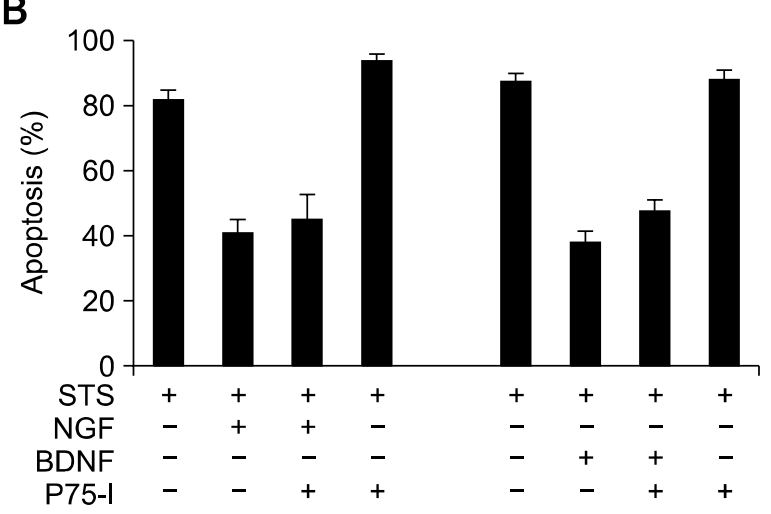

C
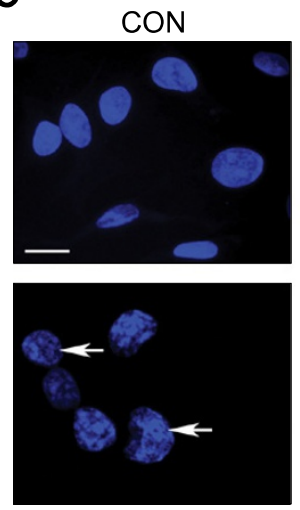

NGF + K252a
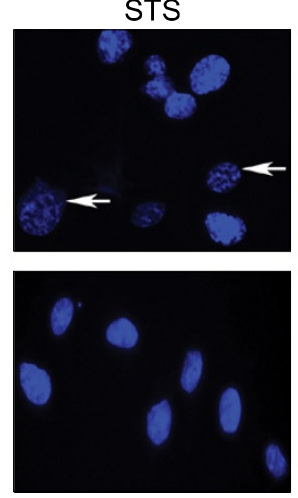

BDNF
$S T S+N G F$
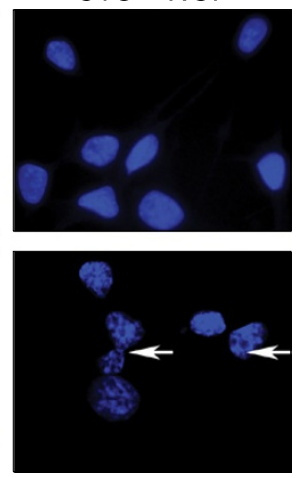

$\mathrm{BDNF}+\mathrm{K} 252 \mathrm{a}$

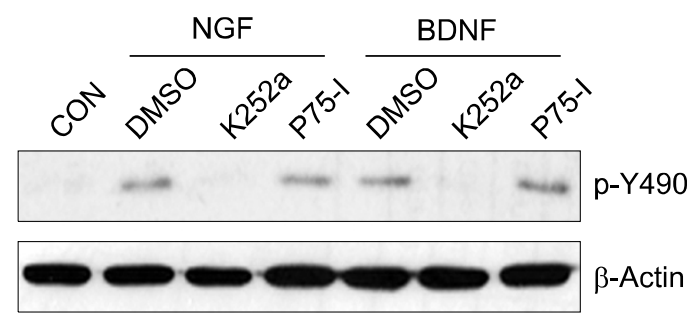

STS

D

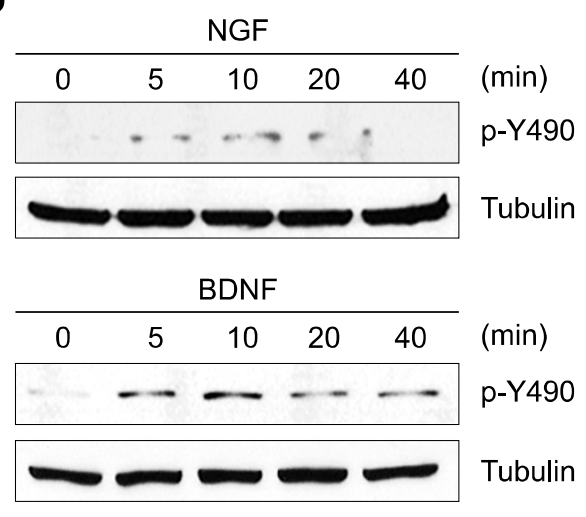

E

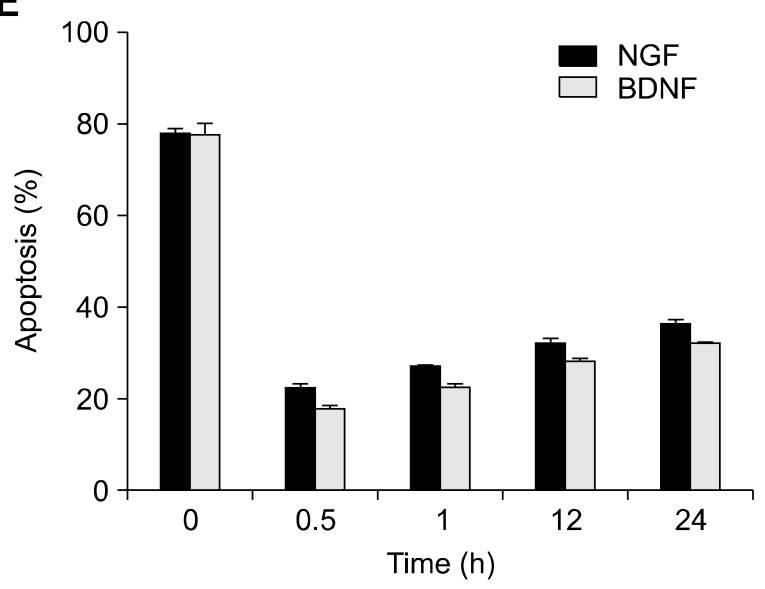

Figure 3. NGF and BDNF protect neuronal apoptosis through Trk signaling. (A and B) H19-7 cells were pretreated with or without K252a or p75NTR inhibitor for $30 \mathrm{~min}$ and incubated with or without $100 \mathrm{ng} / \mathrm{ml} \mathrm{NGF}$ or BDNF for additional an hour. The cells were then exposed to $100 \mathrm{nM} \mathrm{STS} \mathrm{in} \mathrm{for} 8 \mathrm{~h}$. ${ }^{*} P$ $<$ 0.05. (C) (left) Images of Trk inhibitor K252a-blocked NGF and BDNF prevented nuclear condensation. H19-7 cells were treated as indicated, and nuclei were stained with DAPI. White arrows inidicate apoptotic and fragmented nuclei. Scale bar $=5 \mu \mathrm{m}$. (right) K252a inhibits phosphorylation of Tyr490. H19-7 cells were treated as indicated and $30 \mu \mathrm{g}$ of cell lysate was immunoprobed with anti-phospho-Tyr490 antibody. (D) Activation of Trk receptors in H19-7 cells by NGF and BDNF. H19-7 cells were treated with NGF or BDNF at the indicated times. Cell lysates then were probed with anti-phospho-Tyr490 antibody. (E) H19-7 cells were pretreated with $100 \mathrm{ng} / \mathrm{ml}$ NGF or BDNF on the indicated times before exposing to STS. Condensed nuclei were counted under the fluorescent microscope and presented under bar graph. 
polymerase (PARP) cleavage, respectively (Figure $1 \mathrm{C} 3^{\text {rd }}$ and $4^{\text {th }}$ panels). The Erk, control was not affected (Figure $1 \mathrm{C} 5^{\text {th }}$ panel). Preincubation of either hippocampal neurons or $\mathrm{H} 19-7$ cells with the cell-permeable, irreversible caspase-3 inhibitor CHO markedly reduced STS-induced cell death (Figure 1D). However, treatment with the caspase inhibitor did not prevent cytochrome $C$ release, and did not fully inhibit caspase-9 cleavage whereas it completely abolished the activation of caspase- 3 and PARP cleavage (Figure 1E). Since neurons undergoing apoptosis are mediated by the apoptosome pathway, they require the release of cytochrome $\mathrm{C}$ and the execution of caspase cascades. Therefore, treatment with STS could mediate neuronal death via apoptosome activation, revealing cytochrome $\mathrm{C}$ release and caspase-cascade activation.

\section{NGF and BDNF provide neuroprotection from STS-induced cell death}

Although controversial reports exist on the expression of TrkA in hippocampal neurons in culture and in vivo, we show here that $\mathrm{H} 19-7$ cells express p75NTR, TrkA, and TrkB receptor genes and their respective proteins by RT-PCR analysis and immunoblotting respectively (Figures $2 \mathrm{~A}$ and $2 \mathrm{~B}$ ). PC12 cells or U87 MG (derived from human malignant glioma) cells, which produce endogenous p75NTR or TrkA, but not TrkB, were used as a control. Immunofluorescent staining with antibodies against p75NTR, TrkA, or TrkB further supports the production of these receptors in this cell line (Figure 2C). From the observation that H19-7 cells express and produce p75NTR, TrkA, and TrkB receptors, we tested whether NGF and/or BDNF protect STS-induced cell death. Pretreatment of cells with both NGF and BDNF for $24 \mathrm{hrs}$ before STS insult substantially decreased PARP cleavage, underscoring the reduction of caspase-3 activity (Figure 2D). Pretreatment of NGF and BDNF before STS insult, reduced the number of apoptotic cells in a dose dependent manner, BDNF was slightly efficient in protecting the cells than NGF at the higher concentration used (50-200 $\mathrm{ng} / \mathrm{ml}$ ) (Figure 2E). To further characterize the prosurvival effect elicited by NGF and BDNF, we examined cleavage of PARP. Proteolytic cleavage of PARP was completely antagonized by NGF and BDNF pretreatment (Figure 2F). Moreover, we also observed that the similar result of neuroprotection effect with shorter time pretreatment (an hour) of both NGF and BDNF (Supplemental Data Figures $1 A-1 C)$. These observations suggest that both NGF and BDNF contribute to the suppression of apoptosis exerted by STS in H19-7 cells.

\section{NGF and BDNF protect neuronal apoptosis through Trk signaling}

It is well known that activation of Trk receptors play a critical role in promoting cell survival. To examine whether Trk activation was required for the neuroprotective effect of NGF and BDNF, we examined the effect of $\mathrm{K} 252 \mathrm{a}$, an inhibitor of Trk family members, and a p75NTR inhibitor on STS insult. In the presence of $\mathrm{K} 252 \mathrm{a}$, both NGF and BDNF fail to show neuroprotection against STS-induced toxicity in H19-7 cells, however in the absence of neurotrophin, K252a did not affect the neurotoxicity of STS (Figure 3A). In contrast, the p75NTR inhibitor did not affect the protective function of NGF or BDNF (Figure 3B). Nuclei with condensed chromatin morphology are shown in Figure 3C. Presumably, both TrkA and TrkB receptors for NGF and BDNF, which are inhibited by $\mathrm{K} 252 \mathrm{a}$, are directly involved in regulation of neuroprotection by NGF and BDNF. Since phosphorylation of Trk receptors by neurotrophins was required for neuronal survival, we further determined the conserved phosphorylation of TrkA/B receptors by anti-phospho-tyrosine 490 antibodies, followed by either NGF or BDNF exposure. Stimulation of hippocampal cells with $100 \mathrm{ng} / \mathrm{ml}$ of NGF for $5 \mathrm{~min}$ elicited specific phosphorylation of tyrosine 490, and was sustained up to $20 \mathrm{~min}$. After $40 \mathrm{~min}$, phosphorylation of Trk receptor (presumably TrkA) by NGF was not detected. In contrast, treatment with 100 $\mathrm{ng} / \mathrm{ml}$ of BDNF for 5 min exhibited phosphorylation, and enhanced phospho-tyrosine-Trk immunoreactivity at $10 \mathrm{~min}$. The phosphorylation status of TrkB was sustained up to 40 min (Figure 3D). Since we observed rapid neuroprotection effect (an hour treatment of growth factor) and sustained effect (24 hours treatment of growth factors) of both NGF and BDNF(Supplemental Data Figures 1A-1C) and our data demonstrated these growth factor mediated neuroprotection was provided maximal protection within $30 \mathrm{~min}$ and sustained for $24 \mathrm{~h}$ (Figure 3E), both NGF and BDNF exert rapid neuroprotective action through Trk receptor activation, although NGF induced the response to a slightly lesser extent, and may sustained this protective effect through their downstream signaling pathway.

\section{Activation of PI3K/Akt pathways is essential for neurotrophin-mediated survival}

Since both NGF and BDNF protect hippocampal cells against STS insult, we further investigated the 
A
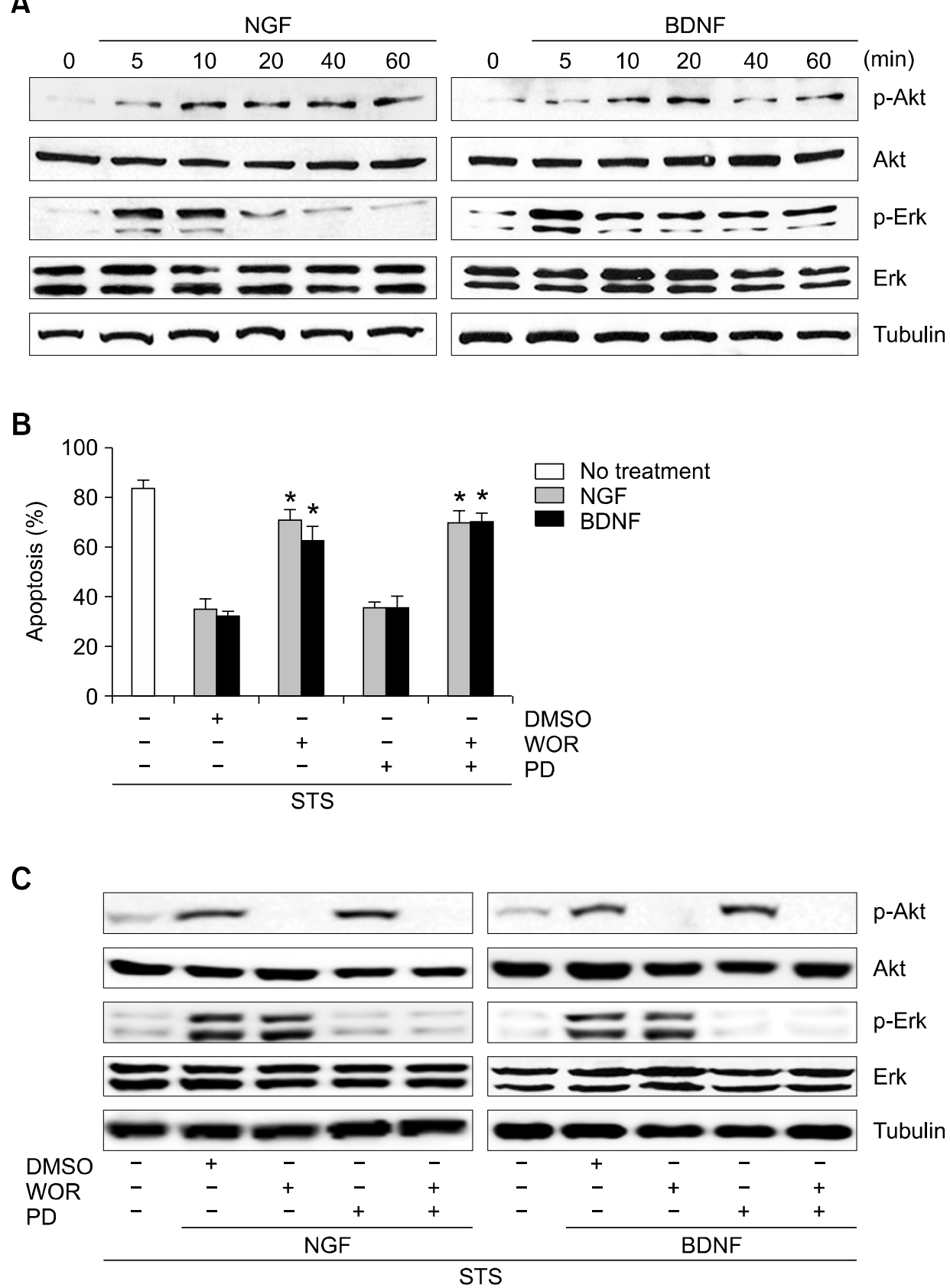

Figure 4. Akt and MAPK are involved in NGF and BDNF protected H19-7 cell survival. (A) H19-7 cells were treated with $100 \mathrm{ng} / \mathrm{ml}$ NGF or BDNF at the indicated times. $30 \mu \mathrm{g}$ of cell lysate was immunoprobed with anti-phospho-Akt, anti-Akt, anti-phospho-Erk, and anti-Erk antibodies. Tubulin was shown as the loading control. (B) H19-7 cells were pretreated with wortmannin $(10 \mu \mathrm{M})$, PD980059 $(10 \mu \mathrm{M})$, or both before applied to $100 \mathrm{ng} / \mathrm{ml} \mathrm{NGF}$ and BDNF. After exposure to STS, nuclear condensation was determined by DAPI staining and counted under a fluorescent microscope. ${ }^{*} P<$ 0.05 . (C) The H19-7 cells were treated as described in (B). $30 \mu \mathrm{g}$ of cell lysate was immunoprobed with the indicated antibodies.

intracellular signaling pathways responsible for the NGF or BDNF-mediated neuroprotective effect. Hippocampal cells were treated with $100 \mathrm{ng} / \mathrm{ml}$ NGF or BDNF at different time points, and the activation of Akt and Erk/MAPK phosphorylation was determined. Figure $4 \mathrm{~A}$ shows that both NGF and BDNF induced phosphorylation of Akt and Erk/MAPK in time dependent manner. Both NGF and BDNF rapidly induced Akt phosphorylation at as early as $5 \mathrm{~min}$, and reached a maximum at around 10-20 min. Activation of Akt remained stable for at least 60 min by both NGF and BDNF stimulation (Figure 4A $1^{\text {st }}$ panel). In contrast, Erk/MAPK phosphorylation by NGF was either transient or weak compared to the Erk/MAPK phosphorylation status by BDNF stimulation. The immunoreactivity of phospho-Erk2 was significantly diminished after $5 \mathrm{~min}$ with NGF and BDNF, although the total amount of Erk1 and Erk2 in cells was present at similar levels (Figure $4 \mathrm{~A} 3^{\text {rd }}$ and $4^{\text {th }}$ panels).

To establish the role of PI3K/Akt and MAPK 
A

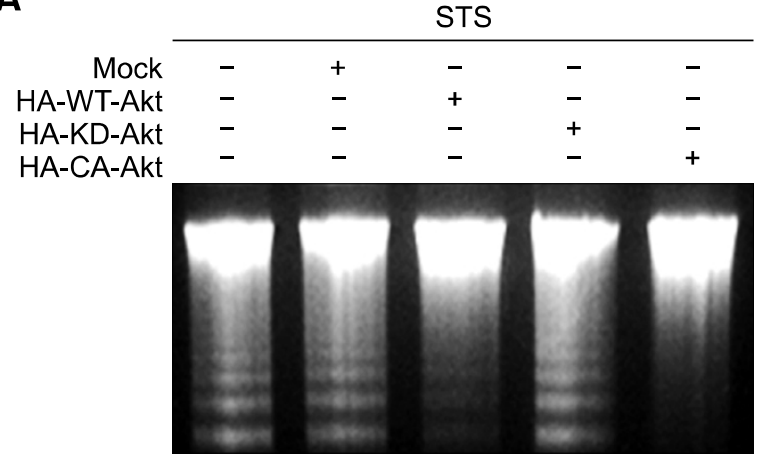

B

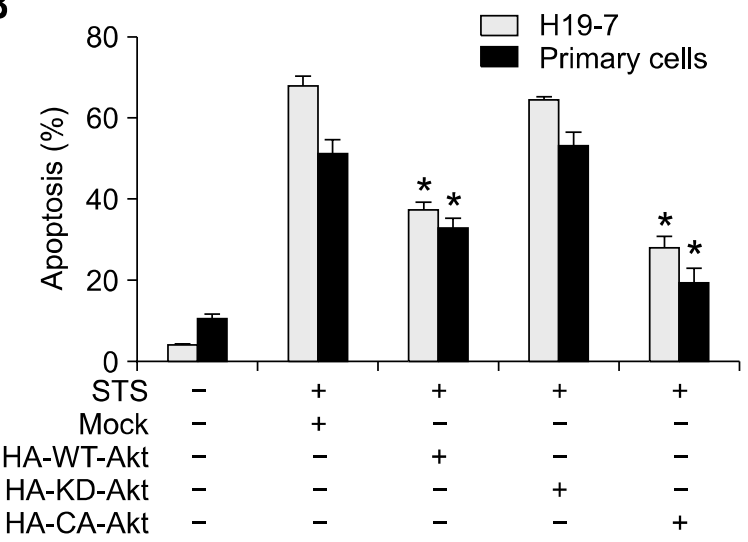

C
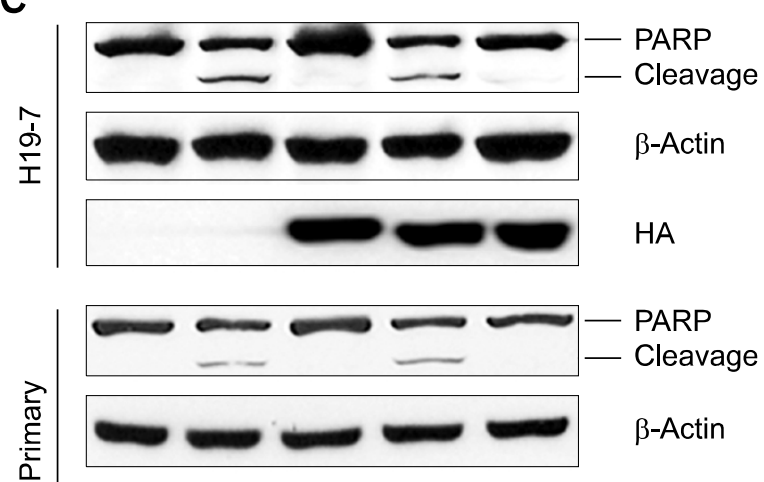

HA

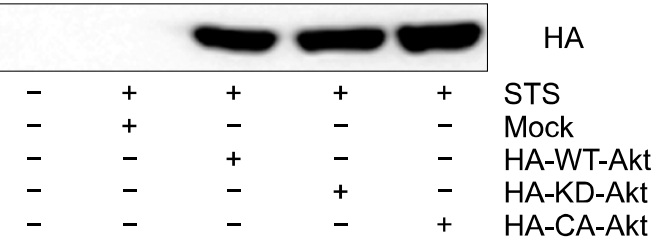

Figure 5. Overexpression of Akt mediates the antiapoptotic effect of NGF and BDNF. (A) H19-7 cells were transfected with the indicated constructs of Akt or the vector control for $24 \mathrm{~h}$. After exposure to $100 \mathrm{nM} \mathrm{STS}$, genomic DNA was extracted and $10 \mu \mathrm{g}$ was loaded in a $2 \%$ agarose gel. (B) Hippocampal neuronal cells and H19-7 cells were transfected with the indicated constructs of Akt. After exposure to STS, the nuclei were stained with DAPI and counted under a fluorescent microscope. ${ }^{*} P<0.05$. (C) Hippocampal neuron cells and H19-7 cells were transfected and treated as described in (B). $30 \mu \mathrm{g}$ of protein lysate was immunoprobed as indicated.

pathways in the prosurvival function of neurotrophins, H19-7 cells were pretreated with PI3K inhibitor, wortmannin, or the MEK (MAPK/Erk kinase) inhibitor PD98509 in STS-induced conditions. Pretreatment with $10 \mu \mathrm{M}$ wortmannin substantially prevented the protective effect of both NGF and BDNF, whereas the MEK inhibitor barely affected the neurotrophin effect (Figure 4B). The combination of wortmannin and PD98509 did not increase the rate of cell death above treatment with wortmannin alone. The corresponding immunoblotting analysis was made regarding the phosphorylation of Akt (Figure 4C). Moreover, it was found that in the absence of neurotrophins, wortmannin treatment exerted up to $20 \%$ cell death while PD98509 treatment elicited only $6 \%$ cell death compared to control conditions (data not shown). Therefore our experiments demonstrate that neuroprotection of both NGF and BDNF are dependent on activation of the PI3K/Akt pathway against STS-mediated apoptosis in hippocampal cells; the MAPK pathway is not involved in this process.

\section{Overexpression of Akt mediates antiapoptotic effects of NGF and BDNF}

To ascertain whether Akt activation is major contributor to the neurotrophin effect of STS-induced apoptosis, H19-7 cells or cultured primary hippocampal neurons were transfected with various forms of Akt and followed by growth factor treatment. Pronounced DNA fragmentation occurred in control cells treated with STS, whereas overexpression of wild type Akt (WT-Akt) or a constitutively active Akt (CA-Akt) dramatically inhibited DNA fragmentation. However, a kinase-dead mutant Akt (KD-Akt) had no effect when treated with STS (Figure 5A lane 4). Quantitative analysis of apoptosis using both primary hippocampal neurons and H19-7 cells correlated with the DNA fragmentation activity 
A

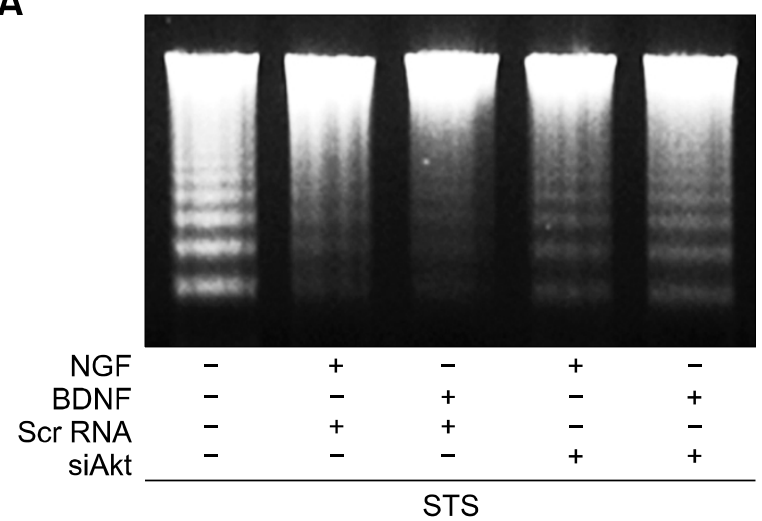

B

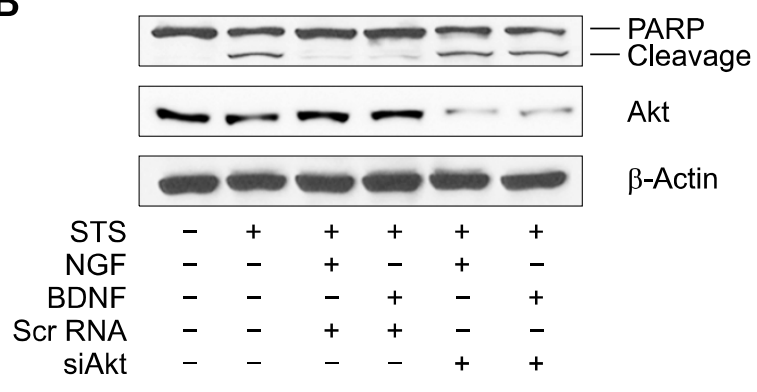

C

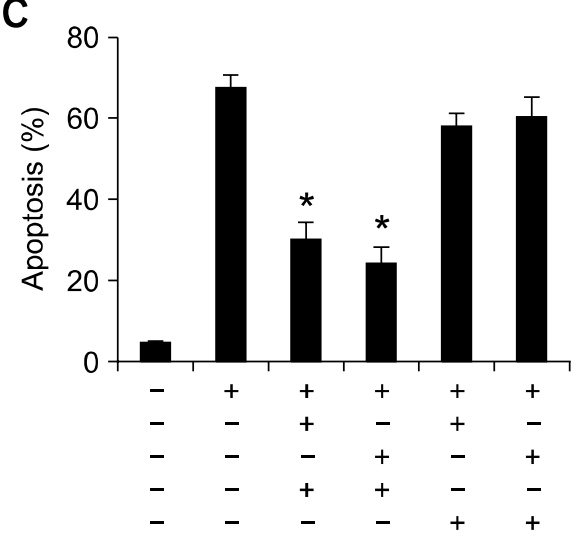

D

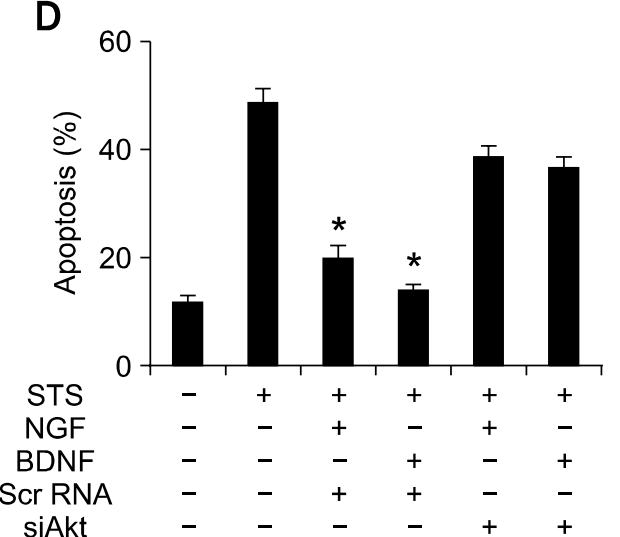

E

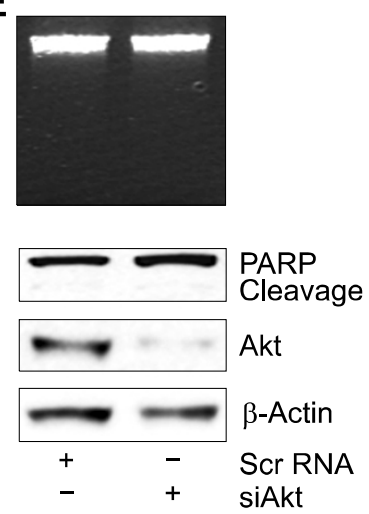

Figure 6. Knockdown of Akt impairs NGF and BDNF mediated cell survival. (A) Scr RNA or si-Akt transfected cells were exposed to $100 \mathrm{nM}$ STS in the presence or absence of NGF or BDNF. Genomic DNA was extracted and $10 \mu \mathrm{g}$ of DNA was loaded on a $\%$ agarose gel. (B) Scr RNA or si-Akt transfected cells were stimulated with NGF or BDNF. After exposure to $100 \mathrm{nM} \mathrm{STS}, 30 \mu \mathrm{g}$ of cell lysate was immunoprobed with anti-PARP antibody. The silencing effect of si-Akt was examined by anti-Akt antibody. (C and D) The H19-7 cells (left) and hippocampal neuron cells (right) were transfected and treated as described in (B). The nuclei were stained with DAPI and counted under a fluorescent microscope. ${ }^{*} P<0.05$. (E) Genomic DNA was extracted from si-Akt trasnfected H19-7 cells and loaded on a 2\% agarose gel (upper panel). $30 \mu \mathrm{g}$ of cell lysate was immunoprobed with anti-PARP antibody. The knockdown effect and the loading control are shown by the anti-Akt and anti- $\beta$ actin antibodies, respectively (lower panels).

(Figure 5B). To further investigate the effect of Akt activation, we examined cleavage of PARP, a well-characterized marker of apoptosis. Proteolytic degradation of PARP was prevented by either overexpression of HA-WT-Akt or HA-CA-Akt under STS toxicity. In contrast, robust PARP cleavage occurred in HA-KD-Akt expressing cells (Figure 5C $1^{\text {st }}$ and $4^{\text {th }}$ panels). Expression of HA-Akt was verified (Figure $5 \mathrm{C} 3^{\text {rd }}$ and $6^{\text {th }}$ panels). These observations suggest that Akt may mediate the antiapoptotic effect of NGF and BDNF through phosphorylation of its downstream targets.

\section{Knockdown of Akt expression impairs NGF and BDNF mediated cell survival}

To further elucidate the role of Akt activation in mediating the antiapoptotic action of neurotrophins, we depleted cells of Akt using si-RNA. H19-7 cells were transfected with Akt-si-RNA for $36 \mathrm{~h}$, followed by STS treatment in the presence or absence of neurotrophins. Both NGF and BDNF treatment inhibited STS-induced DNA fragmentation in wild-type cells. In contrast, depletion of Akt elicited substantial DNA fragmentation regardless of NGF or BDNF treatment (Figure 6A). The PARP cleavage pattern was consistent with DNA fragmentation (Figure 6B upper). Endogenous Akt levels were evidently decreased, whereas the actin loading control was not affected (Figure 6B middle and bottom). Quantitative analysis of cell death using DAPI staining demonstrated a similar effect (Figures 6C and 6D). However, knockdown of Akt itself, without apoptotic stimulation dose, did not impair cell survival, underscoring that Akt has three isoforms and they are redundant (Figure 6E). These results strongly suggest that Akt activation via stimulation by NGF and BDNF plays a critical 
role in preventing apoptotic cell death elicited by STS insult in hippocampal cells.

\section{Discussion}

In the current study, we demonstrated that NGF and BDNF protect hippocampal progenitor cells from apoptotic death against STS toxicity by influencing at the level of, or upstream of, caspase- 3 activation. Neuroprotection by NGF and BDNF was shown to be dependent on the activation of the TrkA and TrkB receptors, which was verified by its phosphorylation. It is well known that Y490 of Trk is autophosphorylated after ligand binding, and this activation plays a direct role in Trk signaling (Loeb et al., 1994; Obermeier et al., 1994). In addition, we also showed that the survival promoting effects of NGF and BDNF were mediated mostly through the activation of the PI3K/Akt pathway rather than the MAPK pathway.

As published evidence of TrkA expression in primary hippocampal neurons was controversial (Ip et al., 1993; Culmsee et al., 2002; Friedman, 2000; Kume et al., 2000), we provided evidence for the expression of TrkA in hippocampal progenitor H19-7 cells using RT-PCR and immunoreaction against anti-TrkA antibody (Figures 2A, 2B and 2C). Accordingly, NGF potently prevents hippocampal H19-7 cell death to the similar extent as BDNF from apoptosis-induced cells by STS (Figures 2D and 2E). The protective effect of both NGF and BDNF observed in this work seems to be mediated by the activation of Trk receptors, presumably, both TrkA and TrkB. Inhibition of Trk receptor signaling with specific Trk inhibitors prevented the survival function of neurotrophins with the exception of the p75NTR inhibitor, suggesting that the blocking of hippocampal cell death occurred by STS required Trk phosphorylation by neurotrophins.

NGF or BDNF mediated neuroprotective signaling in hippocampal neurons is most likely through the activation of the PI3K/Akt pathway, as only blocking PI3K/Akt signaling with the pharmacological inhibitor wortmannin disturbed the neuroprotective effect of both neurotrophins. Activation of the MAPK pathway appears not to be involved, as the MAPK pathway inhibitor PD98059 was ineffective in altering the neuroprotective effect (Figure 4B). These results are in accordance with a recent study suggesting that MAPK was not implicated in the protective effects of BDNF in primary cultured neurons (Bonni et al., 1999; Zheng and Quirion, 2004). Indeed, PI3K/Akt signaling was characterized as the major regulator of neurotrophin mediated survival for various types of neurons including PC12 cells, cerebellar granule cells, sympathetic, sensory, and motor neurons (Yao and Cooper, 1995; Dudek et al., 1997; Crowder and Freeman, 1998; Hetman et al., 1999; Sarmiere and Freeman, 2001). NGF stimulation resulted in a transient activation of MAPK, and BDNF treatment exerted a transient and sustained MAPK activation in hippocampal cells (Figure 4A). However, there was little difference of neuroprotective effect between NGF and BDNF under STS insult (Figure 3). It is possible that the different activation pattern of MAPK by NGF and BDNF may differentially contribute to the differentiation of H19-7 cells. For example, NGF treatment has been shown to induce differentiation of PC12 cells, which is regulated by sustained activation of MAPK (Kao et al., 2001). Thus the PI3K/Akt pathway may preferentially regulate both NGF and BDNF-mediated cell survival.

Overexpression of Akt not only blocks DNA fragmentation, but also suppresses casapse-3 substrate PARP degradation under growth factor stimulation (Figures $5 \mathrm{~A}$ and $5 \mathrm{C}$ ). However, a kinase-dead Akt mutant failed to suppress either PARP cleavage or DNA degradation in the presence of growth factor treatment, suggesting that Akt kinase activity is necessary for antiapoptotic actions of neurotrophins. In addition, knockdown of Akt stimulated PARP cleavage and DNA degradation (Figures 6A and 6B), and neither NGF nor BDNF stimulation could restore its neuroprotection function. These findings indicate that Akt is important for mediating the effect of neurotrophin. Through Trk receptor activation in hippocampal cells and/or Akt mediates neurotrophin signaling through phosphorylation of its downstream targets. Evidence shows that Akt is implicated in antagonizing neuronal apoptosis upon neurotrophin stimulation. Akt has been shown to mediate IGF-1 induced survival of cultured cerebellar granule cells (Dudek et al., 1997) and NGF-dependent survival of sympathetic neurons (Kaplan and Miller, 2000). The exact mechanism by which Akt mediates the survival effect of NGF and BDNF in cultured hippocampal neurons remains to be precisely understood. It is well accepted that Akt regulates apoptosis by impinging on the activity of proteins and gene expression both directly and indirectly. For example, Akt is known to phosphorylate the proapoptotic protein BAD or caspase-9, inhibiting their proapoptotic function (del Peso et al., 1997; Cardone et al., 1998). In addition, Akt is known to phosphorylate the forkhead transcription factor, FoxO, thereby inhibiting expression of death genes (Biggs et al., 1999; Brunet et al., 1999). 
Accordingly, Akt mediates cell survival at different levels depending on cell type, target availability, or transcriptional regulation. Further studies will be necessary to verify the specific downstream events responsible for the neuroprotective effect of NGF and BDNF in hippocampal neurons. Collectively, our findings demonstrate that the neuroprotective function of both NGF and BDNF requires the activation of PI3K/Akt signaling through phosphorylation of the Trk receptor from apoptotic insult.

\section{Methods}

\section{Cell cultures and chemicals}

PC12 cells were maintained in Dulbecco's Modified Eagle's Medium (DMEM) with 10\% fetal bovine serum (FBS), $5 \%$ horse serum, and 100 units of penicillin-streptomycin (PS). U87 cells were maintained in DMEM with $10 \%$ FBS and 100 units PS. Both PC12 and U87 cells were cultured at $37^{\circ} \mathrm{C}, 5 \% \mathrm{CO}_{2}$ in a humidified incubator. $\mathrm{H} 19-7$ cells were maintained in DMEM with $10 \% \mathrm{FBS}, 2 \mu \mathrm{g} / \mathrm{ml} \mathrm{G} 418$, and $0.001 \mathrm{mg} / \mathrm{ml}$ puromycin and cultured at $34^{\circ} \mathrm{C}, 5 \% \mathrm{CO}_{2}$ in a humidified incubator. Staurosporine, nerve growth factor (NGF), brain derived neurotrophic factor (BDNF), caspase 3 inhibitor I, K252a, p75NTR inhibitor, wortmannin, and PD98059 were purchased from Calbiochem (San Diego, CA). Anti-PARP, anti-caspase 3, anti-caspase 9, anti-cytochrome C, anti-Erk, anti-phospho-Erk, anti-Akt, anti-phospho-Akt and anti-phosphoTrk-Y490 antibodies were purchased from Cell Signaling Technology (Danvers, MA). Anti-TrkA, anti-TrkB and anti-p75NTR antibodies were obtained from Upstate Chemicon (Temecula, CA). Anti-tubulin and anti- $\beta$ actin antibodies were from Santa Cruz Biotechnology (Santa Cruz, CA). All other chemicals were purchased from Sigma (St. Louis, MO).

\section{RT-PCR}

Total RNA of H19-7 cells was extracted with TRIzol ${ }^{\circledR}$ reagent (Invitrogen, Carlsbad, CA) according to manufacturer's instructions. The reverse transcription reaction was performed using the Superscript IIM $^{\mathrm{TM}}$ kit (Invitrogen). Expression of TrkA, TrkB and p75NTR was verified by GoTaq $^{\circledR}$ Green Master mix (Promega, Madison WI). Primers used for amplification were as follows: TrkA, forward 5'-AGGTGGCTGCTGGTATGGT-3' and reverse 5'-TCGCCTCAGTGTTGGAGAG-3'; TrkB, forward 5'- TGCTGTGGTGGTGATTGCCTCTGTG -3' and reverse 5'-GTTCTCCCTACCAAGCAGTTCCGG-3'; p75NTR, forward 5'-CCAGCAGACCCACACACAGACTG-3' and reverse 5'-CCCTACACAGAGATGCTCGGTT C-3'.

\section{Immunostaining}

Cells were grown on coverslips in 24-well plates. After growth, cells were fixed in PBS containing $4 \%$ paraformaldehyde for $15 \mathrm{~min}$, permeabilized in PBS containing $0.25 \%$ Triton X-100 for $10 \mathrm{~min}$, and blocked in 2\% BSA for $30 \mathrm{~min}$. Cells were immunostained using antibodies against anti-TrkA, anti-TrkB or anti-p75NTR with
anti-rabbit-AlexaFluor-488 antibody (1:1000). Nuclei were counterstained with 4, 6-diamidino-2-phenylindole (DAPI). Imagines were observed under an Axiophot II fluorescent microscope (Zeiss, Oberkochen, Germany). Apoptotic rate was determined from a total 500 cells from different fields, and calculated as means \pm the standard error from three independent experiments. Morphological changes in nuclear chromatin of cells undergoing apoptosis were detected by DAPI. Only nuclei possessing multiple condensed and aggregated chromatins were counted. All data were statistically analyzed by student's $t$-test and arrows indicate condensed chromatin morphology.

\section{Immunoblotting analysis}

The cells were washed and harvested in ice-cold PBS and subsequently lysed in lysis buffer (50 mM Tris, pH 7.4, 40 $\mathrm{mM} \mathrm{NaCl}, 1 \mathrm{mM}$ EDTA, $0.5 \%$ Triton X-100, $1.5 \mathrm{mM}$ $\mathrm{Na}_{3} \mathrm{VO}_{4}, 50 \mathrm{mM} \mathrm{NaF}, 10 \mathrm{mM}$ sodium pyrophosphate, 10 $\mathrm{mM}$ glycerolphosphate, $1 \mathrm{mM}$ PMSF, and $10 \mathrm{mM}$ protease inhibitor cocktail). $30 \mu \mathrm{g}$ of each cell lysate was used for SDS-PAGE electrophoresis and immunoblotting. Immunocomplexes were visualized with enhanced chemiluminescence reagent (Pierce).

\section{Detection of released cytochrome $\mathbf{C}$}

The procedure has been described as "S-cytosol preparation using a sucrose-containing buffer" (Liu et al., 1996). Briefly, cells were treated for the indicated time with STS with or without $\mathrm{CHO}$. The cells were pelleted, washed with ice-cold phosphate-buffered saline (PBS) and resuspended in 5 volumes of buffer $(20 \mathrm{mM}$ Hepes $[\mathrm{pH}$ 7.5], $10 \mathrm{mM} \mathrm{KCl}, 1.5 \mathrm{mM} \mathrm{MgCl}_{2}, 1 \mathrm{mM}$ EDTA, $1 \mathrm{mM}$ EGTA, $1 \mathrm{mM}$ DTT and $0.1 \mathrm{mM}$ PMSF), supplemented with protease inhibitor and $250 \mathrm{mM}$ sucrose. After incubation on ice for $15 \mathrm{~min}$, the cells were gently broken by douncing with a sandpaper-polished piston. Cells were then centrifuged at $1,000 \mathrm{~g}$ for $10 \mathrm{~min}$ to remove the nuclei and the supernatant was further centrifuged at $100,000 \mathrm{~g}$ for 30 min. The resulting supernatant was used for immunoblotting of cytochrome $\mathrm{C}$.

\section{Supplemental data}

Supplemental Data include a figure and can be found with this article online at http://e-emm.or.kr/article/article_files/ SP-42-8-7.pdf.

\section{Acknowledgments}

This research was supported by a grant (NI-1) from Brain Research Center of the 21st Century Frontier Research Program funded by the Ministry of Education, Science and Technology, the Republic of Korea. We thank Dr. Chang-Dae Bae at Sungkyunkwan University for his generous gift of $\mathrm{H} 19-7$ cells

\section{References}

Barbacid M. Neurotrophic factors and their receptors. Curr 


\section{Opin Cell Biol 1995;7:148-55}

Bates B, Rios M, Trumpp A, Chen C, Fan G, Bishop JM, Jaenisch R. Neurotrophin-3 is required for proper cerebellar development. Nat Neurosci 1999;2:115-7

Biggs WH, 3rd, Meisenhelder J, Hunter T, Cavenee WK Arden KC. Protein kinase B/Akt-mediated phosphorylation promotes nuclear exclusion of the winged helix transcription factor FKHR1. Proc Natl Acad Sci USA 1999;96:7421-6

Bonni A, Brunet A, West AE, Datta SR, Takasu MA, Greenberg ME. Cell survival promoted by the Ras-MAPK signaling pathway by transcription-dependent and -independent mechanisms. Science 1999;286:1358-62

Brunet A, Bonni A, Zigmond MJ, Lin MZ, Juo P, Hu LS, Anderson MJ, Arden KC, Blenis J, Greenberg ME. Akt promotes cell survival by phosphorylating and inhibiting a Forkhead transcription factor. Cell 1999;96:857-68

Brunet A, Datta SR, Greenberg ME. Transcription-dependent and -independent control of neuronal survival by the PI3K-Akt signaling pathway. Curr Opin Neurobiol 2001; 11:297-305

Cardone MH, Roy N, Stennicke HR, Salvesen GS, Franke TF, Stanbridge E, Frisch S, Reed JC. Regulation of cell death protease caspase- 9 by phosphorylation. Science 1998;282: 1318-21

Cellerino A. Expression of messenger RNA coding for the nerve growth factor receptor trkA in the hippocampus of the adult rat. Neuroscience 1996;70:613-6

Chao MV. Neurotrophins and their receptors: a convergence point for many signalling pathways. Nat Rev Neurosci 2003;4:299-309

Choi DW. Glutamate receptors and the induction of excitotoxic neuronal death. Prog Brain Res 1994;100:47-51

Crowder RJ, Freeman RS. Phosphatidylinositol 3-kinase and Akt protein kinase are necessary and sufficient for the survival of nerve growth factor-dependent sympathetic neurons. J Neurosci 1998;18:2933-43

Crowley C, Spencer SD, Nishimura MC, Chen KS Pitts-Meek S, Armanini MP, Ling LH, McMahon SB, Shelton $D L$, Levinson $A D$, Phillips HS. Mice lacking nerve growth factor display perinatal loss of sensory and sympathetic neurons yet develop basal forebrain cholinergic neurons. Cell 1994;76:1001-11

Culmsee C, Semkova I, Krieglstein J. NGF mediates the neuroprotective effect of the beta2-adrenoceptor agonist clenbuterol in vitro and in vivo: evidence from an NGF-antisense study. Neurochem Int 1999;35:47-57

Culmsee C, Gerling N, Lehmann M, Nikolova-Karakashian M, Prehn JH, Mattson MP, Krieglstein J. Nerve growth factor survival signaling in cultured hippocampal neurons is mediated through TrkA and requires the common neurotrophin receptor P75. Neuroscience 2002;115:1089-108

Datta SR, Dudek H, Tao X, Masters S, Fu H, Gotoh Y, Greenberg ME. Akt phosphorylation of BAD couples survival signals to the cell-intrinsic death machinery. Cell 1997; $91: 231-41$ del Peso L, Gonzalez-Garcia M, Page C, Herrera R, Nunez G. Interleukin-3-induced phosphorylation of BAD through the protein kinase Akt. Science 1997;278:687-9

Dudek H, Datta SR, Franke TF, Birnbaum MJ, Yao R, Cooper GM, Segal RA, Kaplan DR, Greenberg ME. Regulation of neuronal survival by the serine-threonine protein kinase Akt. Science 1997;275:661-5

Eves EM, Tucker MS, Roback JD, Downen M, Rosner MR, Wainer $\mathrm{BH}$. Immortal rat hippocampal cell lines exhibit neuronal and glial lineages and neurotrophin gene expression. Proc Natl Acad Sci USA 1992;89:4373-7

Eves EM, Kwon J, Downen M, Tucker MS, Wainer BH, Rosner MR. Conditional immortalization of neuronal cells from postmitotic cultures and adult CNS. Brain Res 1994;656:396-404

Friedman WJ. Neurotrophins induce death of hippocampal neurons via the p75 receptor. J Neurosci 2000;20:6340-6

Goldberg JL, Barres BA. The relationship between neuronal survival and regeneration. Annu Rev Neurosci 2000;23: 579-612

Hetman M, Kanning K, Cavanaugh JE, Xia Z. Neuroprotection by brain-derived neurotrophic factor is mediated by extracellular signal-regulated kinase and phosphatidylinositol 3-kinase. J Biol Chem 1999;274: 22569-80

Huang EJ, Reichardt LF. Trk receptors: roles in neuronal signal transduction. Annu Rev Biochem 2003;72:609-42

Ip NY, McClain J, Barrezueta NX, Aldrich TH, Pan L, Li Y, Wiegand SJ, Friedman B, Davis S, Yancopoulos GD. The alpha component of the CNTF receptor is required for signaling and defines potential CNTF targets in the adult and during development. Neuron 1993;10:89-102

Jacobsen MD, Weil M, Raff MC. Role of Ced-3/ICE-family proteases in staurosporine-induced programmed cell death. J Cell Biol 1996;133:1041-51

Kao S, Jaiswal RK, Kolch W, Landreth GE. Identification of the mechanisms regulating the differential activation of the mapk cascade by epidermal growth factor and nerve growth factor in PC12 cells. J Biol Chem 2001;276:18169-77

Kaplan DR, Miller FD. Signal transduction by the neurotrophin receptors. Curr Opin Cell Biol 1997;9:213-21

Kaplan DR, Miller FD. Neurotrophin signal transduction in the nervous system. Curr Opin Neurobiol 2000;10:381-91

Klesse LJ, Meyers KA, Marshall CJ, Parada LF. Nerve growth factor induces survival and differentiation through two distinct signaling cascades in PC12 cells. Oncogene 1999;18:2055-68

Klesse LJ, Parada LF. p21 ras and phosphatidylinositol-3 kinase are required for survival of wild-type and NF1 mutant sensory neurons. J Neurosci 1998;18:10420-8

Koh S, Chang P, Collier TJ, Loy R. Loss of NGF receptor immunoreactivity in basal forebrain neurons of aged rats: correlation with spatial memory impairment. Brain Res 1989;498:397-404

Kops GJ, de Ruiter ND, De Vries-Smits AM, Powell DR, Bos 
$\mathrm{JL}$, Burgering BM. Direct control of the Forkhead transcription factor AFX by protein kinase B. Nature 1999; 398:630-4

Kume T, Nishikawa $\mathrm{H}$, Tomioka $\mathrm{H}$, Katsuki $\mathrm{H}$, Akaike A, Kaneko S, Maeda T, Kihara T, Shimohama S. p75-mediated neuroprotection by NGF against glutamate cytotoxicity in cortical cultures. Brain Res 2000;852:279-89

Lee TH, Kato H, Pan LH, Ryu JH, Kogure K, Itoyama Y. Localization of nerve growth factor, trkA and P75 immunoreactivity in the hippocampal formation and basal forebrain of adult rats. Neuroscience 1998;83:335-49

Levi-Montalcini R. The nerve growth factor 35 years later. Science 1987;237:1154-62

Liu X, Kim CN, Yang J, Jemmerson R, Wang X. Induction of apoptotic program in cell-free extracts: requirement for dATP and cytochrome c. Cell 1996;86:147-57

Loeb DM, Stephens RM, Copeland T, Kaplan DR, Greene LA. A Trk nerve growth factor (NGF) receptor point mutation affecting interaction with phospholipase C-gamma 1 abolishes NGF-promoted peripherin induction but not neurite outgrowth. J Biol Chem 1994;269:8901-10

Martin LJ, Al-Abdulla NA, Brambrink AM, Kirsch JR, Sieber FE, Portera-Cailliau C. Neurodegeneration in excitotoxicity, global cerebral ischemia, and target deprivation: A perspective on the contributions of apoptosis and necrosis. Brain Res Bull 1998;46:281-309

Meyer-Franke A, Wilkinson GA, Kruttgen A, Hu M, Munro E, Hanson MG Jr, Reichardt LF, Barres BA. Depolarization and cAMP elevation rapidly recruit TrkB to the plasma membrane of CNS neurons. Neuron 1998;21:681-93

Miller TM, Tansey MG, Johnson EM Jr, Creedon DJ. Inhibition of phosphatidylinositol 3-kinase activity blocks depolarization- and insulin-like growth factor I-mediated survival of cerebellar granule cells. J Biol Chem 1997; 272:9847-53

Muragaki Y, Timothy N, Leight S, Hempstead BL, Chao MV, Trojanowski JQ, Lee VM. Expression of trk receptors in the developing and adult human central and peripheral nervous system. J Comp Neurol 1995;356:387-97

Obermeier A, Bradshaw RA, Seedorf K, Choidas A, Schlessinger J, Ullrich A. Neuronal differentiation signals are controlled by nerve growth factor receptor/Trk binding sites for SHC and PLC gamma. EMBO J 1994;13:1585-90

Olney JW, Sharpe LG. Brain lesions in an infant rhesus monkey treated with monsodium glutamate. Science 1969;166:386-8

Patapoutian A, Reichardt LF. Trk receptors: mediators of neurotrophin action. Curr Opin Neurobiol 2001;11:272-80
Philpott KL, McCarthy MJ, Klippel A, Rubin LL. Activated phosphatidylinositol 3-kinase and Akt kinase promote survival of superior cervical neurons. J Cell Biol 1997;139: 809-15.

Sarmiere PD, Freeman RS. Analysis of the NF-kappa B and $\mathrm{PI}$ 3-kinase/Akt survival pathways in nerve growth factor-dependent neurons. Mol Cell Neurosci 2001;18: 320-31

Seo SR, Seo JT. Calcium overload is essential for the acceleration of staurosporine-induced cell death following neuronal differentiation in PC12 cells. Exp Mol Med 2009;41:269-76

Skaper SD, Floreani M, Negro A, Facci L, Giusti P. Neurotrophins rescue cerebellar granule neurons from oxidative stress-mediated apoptotic death: selective involvement of phosphatidylinositol 3-kinase and the mitogen-activated protein kinase pathway. J Neurochem 1998;70:1859-68

Smeyne RJ, Klein R, Schnapp A, Long LK, Bryant S, Lewin A, Lira SA, Barbacid M. Severe sensory and sympathetic neuropathies in mice carrying a disrupted Trk/NGF receptor gene. Nature 1994;368:246-9

Takei N, Tanaka O, Endo Y, Lindholm D, Hatanaka H. BDNF and NT-3 but not CNTF counteract the Ca2+ ionophore-induced apoptosis of cultured cortical neurons: involvement of dual pathways. Neuropharmacology 1999; 38:283-8.

Vaillant AR, Mazzoni I, Tudan C, Boudreau M, Kaplan DR, Miller FD. Depolarization and neurotrophins converge on the phosphatidylinositol 3-kinase-Akt pathway to synergistically regulate neuronal survival. J Cell Biol 1999;146:955-66.

Xia Z, Dickens M, Raingeaud J, Davis RJ, Greenberg ME. Opposing effects of ERK and JNK-p38 MAP kinases on apoptosis. Science 1995;270:1326-31

Yao R, Cooper GM. Requirement for phosphatidylinositol-3 kinase in the prevention of apoptosis by nerve growth factor. Science 1995;267:2003-6

Zhang Y, Tatsuno T, Carney JM, Mattson MP. Basic FGF, NGF, and IGFs protect hippocampal and cortical neurons against iron-induced degeneration. J Cereb Blood Flow Metab 1993;13:378-88

Zheng WH, Quirion R. Comparative signaling pathways of insulin-like growth factor-1 and brain-derived neurotrophic factor in hippocampal neurons and the role of the PI3 kinase pathway in cell survival. J Neurochem 2004;89:844-52

Zipfel GJ, Babcock DJ, Lee JM, Choi DW. Neuronal apoptosis after CNS injury: the roles of glutamate and calcium. J Neurotrauma 2000;17:857-69 


\section{Erratum}

Truong LX Nguyen ${ }^{1}$, Chung Kwon Kim ${ }^{1}$, Jun-Hee Cho ${ }^{4}$, Kyung-Hoon Lee ${ }^{2,3}$ and Jee-Yin Ahn ${ }^{1,3,5}$

Neuroprotection signaling pathway of nerve growth factor and brain-derived neurotrophic factor against staurosporine induced apoptosis in hippocampal H19-7 cells

Exp Mol Med 2010;42:583-595

The authors would like to amend the title as shown below.

Neuroprotection signaling pathway of nerve growth factor and brain-derived neurotrophic factor against staurosporine induced apoptosis in hippocampal H19-7/IGF-IR

The authors apologize for any inconvenience they may have caused. 